\title{
Under What Conditions Do Presidents Resort to Decree Power? Theory and Evidence from the Brazilian Case
}

\author{
Carlos Pereira \\ University of São Paulo \\ Timothy J. Power \\ Florida International University \\ Lucio Rennó \\ University of Arizona
}

\begin{abstract}
The emerging literature on executive decree authority has generated important insights, but it has tended to select on the dependent variable (decrees), rather than view decrees as one of several possible ways that presidents can initiate policies. This article examines the conditions under which presidents resort to extraordinary rather than ordinary means of legislative initiative. Unilateral action theory claims that presidents will resort to decrees in unfavorable political environments, while delegation theory claims that decrees will flourish when the president is more politically secure. A study of four Brazilian presidents between 1988 and 1998 yields inconsistent support for both theories. Presidential popularity is only weakly related to the use of decree authority, but executive-legislative relations - especially coalition management via multiparty cabinets - is a more reliable predictor. Neither unilateral action theory nor delegation theory can fully account for the wide variation in the legislative strategies of presidents.
\end{abstract}

$\mathbf{O}$ ver the past century, a global trend in democratic regimes has been the incremental transfer of policymaking power from elected assemblies to the executive branch. In presidential systems, this shift in relative power has been accompanied by a proliferation of institutional devices that allow executives to choose from among a wide range of policy-initiating instruments (Carey and Shugart 1998; Shugart and Carey 1992). These range from direct introduction of legislation in Congress (not available to the U.S. president, but to many others), to expedited consideration of bills (fast-track and urgency mechanisms), to executive orders and rulemaking power, and even to presidential decrees with immediate force of law. As the menu of presidential options has lengthened, the game of executive-legislative relations in presidential regimes has grown more complex.

Scholars have been disproportionately attracted to the most dramatic and controversial manifestations of executive initiative. In the United States, a significant

THE JOURNAL OF POLITICS, Vol. 67, No. 1, February 2005, Pp. 178-200

(C) 2005 Southern Political Science Association 
literature has appeared on the paraconstitutional mechanism of executive orders, and in comparative politics, scholars are building a considerable body of research on presidential decree authority (e.g., Carey and Shugart 1998). The increasing presidential recourse to executive orders or decree power is a subject worthy of serious inquiry. However, one shortcoming of this literature is its tendency to select on the dependent variable - that is, scholars make the volume of executive orders or decree power the object of study, often forgetting that these presidential actions represent a prior choice from a menu of options. If, instead of focusing on decrees in and of themselves, we make presidential choice the dependent variable, we can see that this variable takes on different values in different environments of presidential power and executive-legislative relations. Conceiving the problem in this way allows us to determine why and under what circumstances presidents choose extraordinary over ordinary mechanisms of legislative initiative.

In this article, our goal is to identify the political conditions under which presidents choose the extraordinary over the ordinary - in other words, why and when do they opt for decrees rather than normal legislation? Brazil is an excellent case study for at least five reasons. First, Brazilian presidents are equipped with an exceptionally wide array of legislative powers, so much so that Shugart and Carey (1992) classified the Brazilian presidency as one of the most powerful in the world. The menu of executive options makes our baseline assumption - that presidents have a range of choices from which to select - a highly realistic one in the Brazilian case. Second, Brazil has experienced uninterrupted democratic rule since 1985 and has operated since 1988 under the same constitution, allowing us to construct a relatively lengthy (1988-1998) time-series database on presidential action. Third, the ten years of our database featured four different presidents, thus affording us considerable variation in leadership styles and executive-legislative relations. Fourth, the literature on political institutions in Brazil is one of the most extensive of any of the Third Wave democracies, allowing us to anchor our question within a research program of insightful contributions and solid data on presidential and congressional behavior. Fifth, some broad similarities with the United States (presidentialism, federalism, bicameralism, a modern bureaucratic state, and general features of size and complexity) make it plausible to draw theoretical inspiration from the study of the U.S. presidency. In sum, executive-legislative relations in Brazil provide a rich, variegated context within which to explore the determinants of presidential strategies.

We view our research design as a first effort toward systematic and contextsensitive research on executive decree authority, an avenue of inquiry that is important to students of the U.S. presidency, to Latin Americanists, and to students of postcommunist democracies alike. Until the mid-1990s, comparative work on this topic had barely moved beyond normative condemnation of the abuse of decrees. In their important edited volume, Carey and Shugart (1998) recast the debate by abandoning the normative bent, by generating a set of 
provocative hypotheses largely informed by delegation theory, and by commissioning a number of empirically grounded case studies. These and other recent studies have shed new light on the origins of decree authority, on its constitutional variations, and on its use by certain presidents under specific conditions of political support. However, what the literature has lacked so far is rigorous, longitudinal, multivariate analyses that would grant us deeper insight into the relationship between conditions of political support and presidential reliance upon decrees. The time-series analysis of Brazil presented here is a first step toward the comparative and case-study research that will be necessary to isolate these political conditions.

In the first section of this article, we examine the U.S. debate on executive orders and introduce analogous arguments that are emerging in the new literature on comparative presidentialism. In examining the rival interpretations of "unilateral action" and "delegation" theory, we introduce the theoretical terrain. In the second section, we explore the details of the Brazilian case, examining formal presidential powers and posing some models based on extant theory. The third section presents our data analysis, and a final section presents our theoretical and comparative conclusions.

\section{Theoretical Insights on Presidential Decree Authority}

Unlike some recent work on executive decree authority, here we do not enter into the debate over why presidential decree powers exist or why they were inserted into specific constitutions. Rather, we are interested in the conditions under which preexisting decree powers are likely to be used. Roughly speaking, there are two major arguments or interpretations that attempt to explain why presidents choose extraordinary over ordinary means of legislative initiative. We refer to these as the unilateral action and delegation theories, and both are well established in the literature on executive-legislative relations in the United States. We first review these perspectives as they apply to the U.S. presidency, and then examine emerging, analogous arguments in the comparative literature.

Unilateral action theory stresses the president's formal capacity to act in isolation from Congress and thus to make law or policy on her own (Moe and Howell 1999). In other words, this perspective views executive orders or decrees as instruments that the executive uses to bypass adversarial or noncooperative legislative bodies. Thus, the executive is the greatest beneficiary of these institutional devices because the president may unilaterally change the status quo if it suits her.

The unilateral action perspective is familiar to students of the U.S. presidency. Gleiber and Shull (1992) claim that presidents will rely more frequently on executive orders when they face strong opposition in Congress. Similarly, Krause and Cohen (1997) assert that executive orders are inversely related to presidential partisan strength in Congress. In the most comprehensive study to date, Mayer (1999) attempts to determine what characteristics of the political environment 
most strongly influence the increase in issuance of executive orders. Mayer's expectations are that conflict-prone political environments - those in which presidents lack strong support in Congress and experience low levels of popularitywill be more conducive to reliance on unilateral action. His data analysis confirms most of his hypotheses, except that divided government (when the majority party in Congress is different from the president's party), contrary to expectations, leads to lower levels of executive order issuing. This comes as a surprise to Mayer, since his hypothesis is that consensual environments should lead to lower use of executive orders, and he finds exactly the opposite.

Mayer's finding about divided government would come as no surprise from an alternative viewpoint, that of delegation theory. This perspective claims that presidents are not the only beneficiaries of executive orders. Executive orders also satisfy the preferences of legislators, because legislators are the actors who delegate this power and who have ample opportunity to overturn (via their own considerable lawmaking powers) any undesirable presidential policies initiated by executive orders. Authors such as Epstein and O'Halloran (1999), Kiewiet and McCubbins (1991), McCubbins, Noll, and Weingast (1987, 1989) derive such assertions from principal-agent theory, according to which the principal (the legislative body) delegates institutional powers to the agent (the executive), expecting to receive benefits in return. These benefits might include information, flexibility in time budgeting, absence of responsibility for public policy, resolution of complex bargaining problems, and other positive returns to the legislature.

Principal-agent theorists strongly criticize the claim of some scholars, such as Lowi (1985), who argue that delegation of legislative power is equivalent to an abdication of Congress's policymaking role. The counterclaim of delegation theory is that what presidents can and cannot do is shaped by the institutional framework (constitution), which itself rests on the consent of legislators. Moreover, Congress has the power to be very specific in designing laws. It can, for instance, write either detailed legislation that leaves the executive with very little latitude to act or pass vague laws that leave the President with broad discretionary authority (Epstein and O'Halloran 1999). In choosing the latter option, which involves agency loss on the part of the assembly, legislators trade off the cost of legislating directly against the electoral benefits they can extract by delegating powers to the executive. However, due to the information asymmetries inherent in these relationships, politicians also run the risk that this discretion might harm their interests. The delegation literature shows that this problem exists and is pervasive and then goes on to show how the parties attempt to deal with it (e.g., Pereira and Mueller 2002).

Turning to presidentialism outside the United States, prior to the 1990s there were few theoretically grounded studies of executive dominance. Most treatments of presidential decree authority, especially in Latin America, were content to speculate superficially about allegedly authoritarian political cultures and socalled rubber-stamp legislatures. But as the research program has advanced over 
the past decade, the delegation and unilateral perspectives developed in the U.S. case have developed analogues in the comparative politics literature.

For example, with regard to unilateral action theory, a recent essay on executive-legislative relations in Latin America by Cox and Morgenstern (2002) argues that "when the president is politically weaker, he typically resorts more frequently to his unilateral powers; when he is politically stronger, he resorts to these powers less often." Minority presidents, realizing that they have little hope of enacting their policies via ordinary law, may decide to "push the envelope" in "constitutionally provocative ways" (Cox and Morgenstern 2002, 450-51).

In contrast, Carey and Shugart are skeptical of unilateralist explanations of decretismo. For these authors, "there are good reasons to expect that within the right institutional format, executive decree can be attractive to legislators as a means of expediting action on policy, even without ceding control over policy to the executive" $(1998,296)$. Legislators may also accede to the expansion of decree authority "because of partisan support for individual executives, because of collective action problems within legislatures, or because of the individual electoral incentives of legislators themselves" (295). Carey and Shugart take aim at what they call the "usurpation interpretation" of presidential decree authority in Latin America. For them, a closer look at the expansion of executive authority almost always reveals the tacit consent of the legislature (delegation).

Tailoring these arguments to the coalitional format of Brazilian presidentialism, Figueiredo and Limongi (2003) see executive decrees as valuable instruments for solving problems of "horizontal bargaining" between the government and its support coalition rather than a means of solving "vertical conflict" between the government and the legislature. In this sense, the use of executive decree authority does not imply conflict but concerted action between the government and its floor voting bloc in the legislature (see also Reich 2002). ${ }^{1}$

Although Cox and Morgenstern draw our attention to unilateralism, and Carey and Shugart as well as Figueiredo and Limongi emphasize delegation, it is important to note the commonalities in their approaches. Both emphasize the interaction of two key variables: formal constitutional powers and the dynamics of political support under multipartism. Reliance on decrees does not derive from the mere existence of decree authority, or from multiparty presidentialism per se, but is rather contingent upon the political environment-most especially the president's degree of support in the assembly. We note that single-country case studies such as ours cannot fully accommodate the subtleties of these hypotheses, because formal constitutional powers are usually held constant - as they were during our Brazilian time series, 1988-1998. However, longitudinal analysis in a single country has the major advantage of allowing for significant variation on the dimensions of political support.

\footnotetext{
${ }^{1}$ The analysis of Figueiredo and Limongi has clear parallels to the analyses by Huber $(1996,1998)$, who shows how French executives use decree authority to prevent previously negotiated deals from falling apart.
} 
The interface of this recent work with U.S. literature on executive orders is readily apparent, especially with regard to legislative support for the president. Modern research on U.S. presidentialism, however, has historically added another variable to the mix: presidential popularity. Neustadt (1960) argued that a president's power vis-à-vis Congress is shaped by his standing with the public, a perspective that has been largely ignored in emerging comparative work. But this omission is not for lack of data - given the increasing availability of public opinion surveys in new democracies, researchers are clearly now in a position to begin including the popularity variable in comparative studies of presidential politics. Therefore, in this article we acquire and analyze the data necessary to introduce a Neustadtian perspective into the emerging debate on executive-legislative relations in Latin America. ${ }^{2}$

Thus, drawing on these insights from both the U.S. and comparative literature, it is possible to elaborate two general hypotheses from the contending theories of delegation and unilateral action.

(1) Following the delegation theory arguments, we should expect an increase in decrees in situations where presidential popularity is high and/or when the president faces a relatively cooperative Congress. If decrees are instruments that also advance the preferences of legislators (Reich 2002), logically they should proliferate during periods of relatively greater consensus between the executive and assemblies.

(2) Alternatively, unilateral action theory predicts an increase in the number of decrees when presidential popularity is low and/or legislators are less supportive of presidential preferences. By resorting to decrees, politically insecure presidents not only find ways of circumventing other institutional actors who might be opposing them, but also enjoy the privilege of position taking, framing policy questions, or delivering directly on promises made to key constituencies. In this view, presidents use executive decree authority as a compensatory strategy to make policy in environments that are more conflictual.

The existing literature provides inconclusive responses for these hypotheses, as researchers have reached contradictory results on the relationship between congressional and public support and the strategic action of the president to rely on executive order. We have already discussed the unexpected findings of Mayer (1999). In another study of the U.S. case, Krause and Cohen (1997) find no statistically significant relationship between presidential popularity and executive order frequency, although the regression coefficient has the expected sign. On the other hand, Cooper argues that presidents are likely to use executive orders "as instruments of expediency to circumvent administrative law" (1986, 235), behavior that would be consistent with a tendency to rely on orders to compensate for

\footnotetext{
${ }^{2}$ To date, Latin American data on presidential popularity have been employed mostly in studies of economic reform rather than of political institutions (e.g., Stokes 2001; Weyland 2002). We are among the first to employ presidential popularity in a study of executive-legislative relations in Latin America.
} 
lack of public and congressional support. Scholars of the U.S. presidency have not yet reached a consensus on these issues.

\section{A Brazilian Test of the Hypotheses: Context, Data, Variables}

Brazil affords us excellent opportunities to test the aforementioned hypotheses given its political system characterized by minority (or coalitional) presidentialism (Abranches 1988; Mainwaring 1993). Compared to the United States, Brazil has greater variance in governmental support in the Chamber of Deputies, more fluctuation in presidential popularity, higher party fragmentation in the legislative and electoral arenas, and greater reliance on instruments of unilateral executive initiative in policymaking. The greater elasticity compared to the case of the United States increases the likelihood of more clearly specifying the impact of the political context on presidential legislative strategies.

Before proceeding to our models, a few remarks on the Brazilian context are in order. ${ }^{3}$ Article 62 of Brazil's Constitution of 1988 allows presidents, in cases of "urgency and relevance," to decree "provisional measures with force of law" (medidas provisórias com força de lei, or MPVs in Brazilian legislative terminology). Based on a similar provision in the Italian constitution, the original formulation of Article 62 stipulated that these decrees would have immediate legal effect but would expire after 30 days if Congress did not convert them into law. However, due to ambiguity in the constitutional language, several paraconstitutional initiatives of the first president to serve under the Constitution of 1988 (José Sarney 1985-1990) shaped the game of executive-legislative relations until 2001. One such initiative was for the executive, not surprisingly, to interpret selfservingly the constitutional requisite of "urgency." A second was to observe very few limits as to what types of policies could be initiated or altered via decree. A third, controversial precedent was to reissue decrees that Congress did not consider within 30 days. In this way, all four presidents between 1988 and 2001 gained impressive agenda-setting powers in the legislature and were able to establish literally hundreds of public policies via the constant issuing and reissuing of decrees. (The Supreme Court tolerated reissues as long as presidents did not try to reintroduce any decree that Congress had specifically rejected.) In Congress, serious disagreements over the extent of decree authority were not resolved until 2001, when, via an accord with President Fernando Henrique Cardoso (1995-2002), Congress amended Article 62 so as to limit presidents to a single reissue of a lapsed decree. The amendment also reduced constitutional ambiguity by specifying a list of issue-areas in which the executive may not resort to decrees. ${ }^{4}$ New patterns have yet to emerge, but from October 1988 until Sep-

\footnotetext{
${ }^{3}$ For additional insights on presidential decree authority in Brazil, see Figueiredo and Limongi (1999, 2003), Power (1998), Amorim Neto and Tafner (2002), Reich (2002), and Pessanha (2002).

${ }^{4}$ The text of the new constitutional amendment is available online at http://www.planalto.gov.br/ ccivil_03/Constituicao/Emendas/Emc/emc32.htm.
} 
TABLE 1

Distribution of MPVs (Presidential Decrees) by Administration, 1988-1998

\begin{tabular}{lrrrr}
\hline & Sarney & Collor & Itamar & Cardoso \\
\hline Total MPVs & 147 & 159 & 505 & 2,609 \\
Reissued & 22 & 70 & 363 & 2,449 \\
Reissues of MPVs of Previous President & 0 & 0 & 0 & 699 \\
Original MPVs & $\mathbf{1 2 5}$ & $\mathbf{8 9}$ & $\mathbf{1 4 2}$ & $\mathbf{1 6 0}$ \\
Converted into Law & 96 & 74 & 71 & 130 \\
Withdrawn/Abrogated by President & 2 & 5 & 5 & 12 \\
Rejected by Congress & 9 & 11 & 0 & 1 \\
Success Rate of Original MPVs* & 76.8 & 83.1 & 50.0 & 81.3 \\
Rejection Rate of Original MPVs & 7.2 & 12.4 & 0 & .6 \\
\hline
\end{tabular}

* The success rate of the Itamar Franco administration is artificially low because nearly 700 decrees were rolled over into the successor administration of Fernando Henrique Cardoso in January 1995.

SOURCE: Brazilian Presidency website (http://www.planalto.gov.br).

tember 2001 formal presidential powers were held constant, thus facilitating timeseries analysis. Brazilian presidents commanded a powerful tool of executive initiative and were not reluctant to use it, as demonstrated by Table 1 .

To test our central hypotheses, we constructed a novel database on presidential action under the Constitution of 1988. Our units of analysis are months. Our time series begins with President José Sarney, who was serving at the time the new Constitution was promulgated on October 5, 1988, and served until March 15, 1990. He was followed by Fernando Collor de Mello (March 1990-September 1992), Itamar Franco (October 1992-December 1994), and Fernando Henrique Cardoso (January 1995-December 2002). We end our coverage at the end of Cardoso's first term in December 1998. Thus we have a maximum of 124 presidency-months, although this is reduced to 116 in the analyses below because of missing data and/or lagging of variables, which causes us to drop the first month of each presidency. Given that the four presidents are responsible for 18 , 31,27 , and 48 months, respectively, this affords us a good mix of political contexts and presidential styles in the data set. For each month, we collected data on contextual aspects of executive-legislative relations, as discussed below.

We are interested not so much in presidential decrees per se as in the choices that presidents make. To explore this question, our dependent variable is a decree reliance ratio. This is expressed as the ratio of medidas provisórias (executive decrees) to the sum of all legislative initiatives introduced by the president. $^{5}$

\footnotetext{
${ }^{5}$ This measure is the inverse of Amorim Neto, Cox, and McCubbins' (2003) Standard Lawmaking Index, which is a ratio of reliance on ordinary means of legislation (projetos de lei and projetos de lei complementar). Our study focuses only on original (first-time) decrees and not the many mechanical reissues (see Table 1), because to use the latter would seriously distort our results. The clearest test of delegation theory and unilateral action theory is provided by a focus on new policies initiated by the president, and these are best captured by the original MPVs.
} 
To examine the political context at hand, we rely on a cluster of independent variables, most of which we lag in the analyses reported below. The first is presidential popularity, which is based on the average of three time series from respected polling institutes (see the appendix for descriptions of all variables and sources). The second is legislative support for the president, expressed (monthly) as the percentage of legislators following the floor voting recommendation (encaminhamento) of the leader of the progovernment coalition (Lider do Governo) in the Chamber of Deputies. In cases where the executive recommends a NO vote, the denominator is the total of votes cast in the house. In cases where the executive recommends a YES vote, the denominator is the total number of seats in the house. ${ }^{6}$ This variable expresses the level of policy preference congruence between the president and Congress as a whole, not just members of the governing coalition. ${ }^{7}$

Our third and fourth political variables were innovated by Octávio Amorim Neto (2002) to assess the political challenges of minority presidentialism. As is typical in Brazil, at no time in our data set did the president belong to a party with an absolute majority of seats in Congress; faced with this situation, presidents attempt to win support by making their cabinets inclusive of as many legislative parties as possible. Brazilian presidentialism is thus coalitional presidentialism and depends on strategies of coalition management similar in many ways to those of prime ministers in the multiparty parliamentary systems of Europe. To tap into this calculus we use, first, Amorim Neto's cabinet size variable, which captures the nominal size of the presidential cabinet's political "coverage" in Congress. This coverage is expressed in terms of the percentage of Chamber seats held by the ministerially represented parties, a value that changes frequently due to cabinet shakeups and to the exclusion/inclusion of nonpolitical ministers. We also employ Amorim Neto's indicator of cabinet coalescence. This measures the degree of proportionality between the pro-presidential parties' share of seats within the government's floor voting coalition in the Chamber and their share of ministerial portfolios. A higher coalescence rate means a more satisfied coalition arrayed behind the president. High coalescence also implies that coalition parties will have greater influence on the presidential agenda and will therefore fight harder to implement it.

\footnotetext{
${ }^{6}$ We use the higher denominator on YES votes in order to capture the ability of the propresidential coalition to marshal its forces on the floor and pass legislation of interest to the executive.

${ }^{7}$ Overall legislative support of the president is obviously related to the dimensions of the formalized propresidential coalition in Congress, but it is not totally encompassed by the latter. In fact, for the entire period the correlations between two of the variables we use to measure coalition management (cabinet size and cabinet coalescence rate) and overall legislative support for the president are .023 and -.0026 , respectively. Presidents negotiate with legislators in numerous ways, such as by authorizing budgetary amendments proposed by federal deputies (Ames 2001; Samuels 2002; Pereira and Rennó 2003) or by allowing them to name allies to jobs in the federal bureaucracy. Hence, overall legislative support of the president should reflect all of these negotiation processes with government, opposition, and neutral legislators.
} 
Taken together, cabinet size and cabinet coalescence measure both the political "width" and "depth" of the presidential support coalition: both its absolute size and the degree of equity in the distribution of ministerial payoffs to the constituent parties. They are two sides of the same coin of coalition management. Hence, we expect a reinforcing impact of cabinet size and coalescence rate on the presidential choice of policymaking instruments. The best way of measuring such a reinforcing impact is through the use of an interaction term between cabinet size and cabinet coalescence, which we also include in our models. This interaction term assumes that for presidents, the payoff of the size of the coalition is in fact conditional upon its degree of coalescence. Presidents may wish to maximize both the size and the coalescence of their support coalitions, but due to numerous obstacles (e.g., the electoral calendar, the disproportional weight of certain states and regions in Congress, counterpressures from governors, and the ease of party switching in Brazil), they often find it difficult to do both simultaneously. By including the interaction term we are able to trace both dimensions of size and proportionality and explore the full range of outcomes of coalition management, from "overperforming" small coalitions to "underperforming" large ones. Recall that for delegation theorists, successful coalition management should result in more presidential decrees, while for unilateral action theorists, successful coalition management should generate fewer presidential decrees. ${ }^{8}$

The five variables described above account for most of the variance in the political context of executive-legislative relations in Brazil. However, in our analysis these central variables are accompanied by a series of necessary controls. One control variable is the size of the presidential agenda, measured as the total amount of legislative initiatives sent by the president to Congress in a given month. This allows for the possibility that as overall presidential activism rises, so too might the share of proposals introduced by urgent and extraordinary means. A second control variable is the electoral cycle. Because election campaigns are associated with reduced legislative activity and the potential for either delegation or abdication of Congressional prerogatives, we include a dummy variable that gauges the disruption to normal parliamentary activity caused by an impending election. Months of presidential and legislative campaigning are coded as 1. We also include a control variable for honeymoon effects. This is scored as 1 for the first three months of the presidential administrations of Collor, Itamar, and Cardoso (but not Sarney, who was a veteran incumbent in 1988), and zero otherwise. Another important control variable captures the reelectability of the president. Traditionally, Brazilian presidents could not seek immediate reelec-

\footnotetext{
${ }^{8}$ A preliminary examination of these hypotheses by Amorim Neto and Tafner (2002) suggested that a lack of coordination between the executive and legislative branches, measured by cabinet coalescence, leads to a greater reliance on decrees by presidents. However, as the authors themselves recognize, their use of annualized observations $(N=12)$ between 1988 and 2000 provides an inconclusive test. The use of monthly observations (maximum $N=124$ ) in our study allows for more variation in the dependent variable and is also more sensitive to short-term changes in coalition management.
} 
tion, and so were lame ducks. Cardoso sought to change this and won the passage of a constitutional amendment allowing immediate reelection (he was reelected in October 1998). This reelectability variable is scored as 0 through June 1997 and 1 thereafter, and affects only Cardoso.

In addition, we recognize that in a study of executive decree authority in a developing country, wherein presidents are routinely beset by grave socioeconomic crises, we must include controls for the very real pressures of macroeconomic management. We therefore include a control variable measuring the lagged monthly inflation rate, using Brazil's consumer price index (INPC). We also include dummy variables for each of the months in which presidents decreed major economic stabilization packages. Failure to include these two controls would seriously distort our results, especially because the months of stabilization plans (Collor Plan, Real Plan, etc.), some of which were introduced by surprise, saw presidents issuing decrees in impressively large batches (Figueiredo and Limongi 1999). The inclusion of these controls for the economic context allows us to focus more clearly on the political context of executive-legislative relations, especially presidential popularity and legislative support. ${ }^{9}$

Finally, a model of presidents' choice of lawmaking instrument must also contemplate variations between administrations due to contextual factors. The period covered by Cardoso's first administration (1995-1998) is quite distinct from that of his predecessors. As Amorim Neto, Cox, and McCubbins (2003) point out, Cardoso was the only president of the current democratic period to be able to form a presidentially led agenda party cartel in the Chamber of Deputies. Our data confirm this insight. Cardoso had higher mean levels of congressional support than the other presidents, and more importantly, such levels were quite stable over time. Cardoso was also much more effective in managing his coalition in Congress. Cabinet size and cabinet coalescence rate are perfectly correlated (Pearson $r$ of 1.0) in the Cardoso period. Hence, Cardoso not only had a larger coalition, but this coalition was very equitably represented in his cabinet. Finally, the first-term Cardoso also enjoyed far higher public support than other presidents, due mostly to the success of his economic stabilization plan and to his personal seriousness and integrity. In other words, Cardoso in 1995-1998 was

\footnotetext{
${ }^{9}$ We have no strong theoretical justification for including a lagged term of the dependent variable on the right-hand side of the equation. Given that the Durbin-Watson is at acceptable levels in all equations, there is no statistical reason for adding the lagged term either. However, we did run equations with the lagged term in order to check for coefficient stability over distinct model specifications. Contrary to Achen's (2000) expectations, the inclusion of the lagged term never obscured the statistically significant and substantive impacts of the other independent variables. The lagged term itself was never statistically significant. We also ran all the regressions using the Prais-Winston correction for serial correlation. Again, the statistical and substantive results remained unaltered, with just minor improvements in the results of the Durbin-Watson test, indicating that the simple OLS results we present are reliable. The coefficients we present in Table 2 are stable and consistent across slight variations in the specification of the model as well as with the use of distinct estimation procedures.
} 
far more politically secure than his predecessors and faced an environment of lower conflict.

This conjunction of factors renders Cardoso's government different from his predecessors. Hence, we hypothesize that the impact of the main political variables in our model, i.e. presidential popularity, Congressional support, and coalition management (size and coalescence) on the executive's choice of lawmaking instrument is conditional upon the period examined. ${ }^{10}$

\section{Data Analysis: The Influence of Conflict and Consensus on Presidents' Choices}

We now proceed to test the relationship between presidents' choice of policy mechanism and political context in a series of multivariate time-series models. Our dependent variable is expressed as the ratio of decrees to all forms of presidentially introduced legislation. ${ }^{11}$ We ran regressions for the entire 1988-1998 period, for the pre-Cardoso subsample (Sarney, Collor, and Itamar), and for the Cardoso subsample (which includes only his first term) in order to verify if there is variation in the impact of the independent variables in the latter two periods. The model specification was kept almost identical across the three samples to increase the comparability of the results. ${ }^{12}$

Our dependent variable is trend stationary as indicated by visual inspection of the variable graphed over time as well as a KPSS test, and the null hypotheses of homoskedastic errors in the different models are never rejected by CookWeisberg tests at the .05 level. No serial correlation was detected in any of the equations, as the results of the Durbin-Watson test very closely approximate the conventionally accepted value of 2.0. Results for the different samples are

\footnotetext{
${ }^{10}$ It would be preferable to run a single equation with dummy interaction effects of the political variables for the two periods. Data limitations prohibit such analysis due to perfect collinearity between cabinet size and cabinet coalescence rate in the Cardoso period. Hence we adopt the secondbest solution: to estimate almost identical models for the different subsamples and then compare them.

${ }^{11}$ Mathematically, the "decree reliance ratio" is MPV/(MPV + PL + PLC). See the appendix for an explanation of these Brazilian parliamentary abbreviations.

${ }^{12}$ The differences in the models are due to the nature of our data. The reelection variable is a constant for the pre-Cardoso period; hence it is dropped from the analysis in that period. The economic plan control is constant during the Cardoso period, so it also drops out. Because cabinet size and cabinet coalescence rate are perfectly correlated in the Cardoso period, they cannot be entered simultaneously in the equation and an interaction term between them cannot be interpreted correctly since both component terms cannot be entered simultaneously along with the interaction term. In Table 2, we choose not to include dummies for the presidents in order to keep the degrees of freedom in the different equations approximately identical. We did, however, run an equation for the entire period with administration dummies included, leaving Cardoso as the excluded category. The dummies for Sarney, Collor, and Itamar were not significant. The constant, which stood for Cardoso, was significant. In the analysis of the entire sample, the inclusion of the dummies changed the direction of the impact of the inflation variable and of popularity, without altering their lack of statistical significance, and removed the statistical significance of the congressional support variable. This further indicates that the impact of the variables is altered when differences in administrations are taken into account.
} 
TABLE 2

OLS Coefficients and Standard Errors of Decree Reliance Index

\begin{tabular}{|c|c|c|c|c|}
\hline DECREE RELIANCE & $\begin{array}{c}\text { ENTIRE } \\
\text { PERIOD } \\
1988-1998\end{array}$ & $\begin{array}{c}\text { PRE- } \\
\text { CARDOSO } \\
\text { 1988-1994 }\end{array}$ & $\begin{array}{c}\text { CARDOSO } \\
1995-1998\end{array}$ & $\begin{array}{c}\text { CARDOSO } \\
1995-1998\end{array}$ \\
\hline LCABINETSIZE & $\begin{array}{l}1.562 \\
(.21)^{* * *}\end{array}$ & $\begin{array}{l}1.101 \\
(.406)^{* * *}\end{array}$ & $\begin{array}{l}1.594 \\
(.426)^{* * *}\end{array}$ & - \\
\hline LCABINETCOALESCENCE & $\begin{array}{rl}-1 & .636 \\
& (.257)^{* * *}\end{array}$ & $\begin{array}{r}-1.829 \\
(.308)^{* * *}\end{array}$ & - & $\begin{array}{l}10.78 \\
(2.879) * * *\end{array}$ \\
\hline INTERACTION & $\begin{array}{c}-.025 \\
(.02)\end{array}$ & $\begin{array}{l}-.069 \\
(3.694)^{*}\end{array}$ & - & - \\
\hline LPOPULARITY & $\begin{array}{l}-.004 \\
(.104)\end{array}$ & $\begin{array}{c}.078 \\
(.121)\end{array}$ & $\begin{array}{l}-1.09 \\
\quad(.438)^{* *}\end{array}$ & $\begin{array}{l}-1.09 \\
\quad(.438)^{* *}\end{array}$ \\
\hline LCONGRESS & $\begin{array}{l}-.339 \\
(.185)^{*}\end{array}$ & $\begin{array}{l}-.604 \\
(.232)^{* *}\end{array}$ & $\begin{array}{l}.570 \\
(.344)^{*}\end{array}$ & $\begin{array}{l}.570 \\
(.344)^{*}\end{array}$ \\
\hline HONEYMOON & $\begin{array}{c}13.8 \\
(10.8)\end{array}$ & $\begin{array}{c}20.1 \\
(14.8)\end{array}$ & $\begin{array}{r}4.45 \\
(16.6)\end{array}$ & $\begin{array}{r}4.45 \\
(16.6)\end{array}$ \\
\hline ELECTORAL CYCLE & $\begin{array}{l}15.2 \\
(8.62)^{*}\end{array}$ & $\begin{array}{c}17.2 \\
(11.1)\end{array}$ & $\begin{array}{l}38.1 \\
(12.5)^{* * *}\end{array}$ & $\begin{array}{l}38.1 \\
(12.5)^{* * *}\end{array}$ \\
\hline AGENDASIZE & $\begin{array}{l}-.125 \\
(.391)\end{array}$ & $\begin{array}{c}-.138 \\
(.498)\end{array}$ & $\begin{array}{l}1.02 \\
(.601)^{*}\end{array}$ & $\begin{array}{l}1.02 \\
(.601)^{*}\end{array}$ \\
\hline REELECTION & $\begin{array}{c}-2.25 \\
(7.48)\end{array}$ & - & $\begin{array}{l}-8.23 \\
(6.61)\end{array}$ & $\begin{array}{c}-8.23 \\
(6.61)\end{array}$ \\
\hline ECONOMIC PLAN & $\begin{array}{l}32.2 \\
(13.4)^{* *}\end{array}$ & $\begin{array}{l}29.9 \\
(14.6)^{* *}\end{array}$ & - & - \\
\hline LINFLATION & $\begin{array}{l}-.197 \\
(.196)\end{array}$ & $\begin{array}{l}-.045 \\
(.243)\end{array}$ & $\begin{array}{l}10.6 \\
(5.91)^{*}\end{array}$ & $\begin{array}{l}10.6 \\
(5.91)^{*}\end{array}$ \\
\hline Constant & $\begin{array}{c}64.56 \\
(12.38)^{* * * *}\end{array}$ & $\begin{array}{c}74.61 \\
(15.17)^{* * *}\end{array}$ & $\begin{array}{l}-5.76 \\
(23.65)\end{array}$ & $\begin{array}{l}-100.35 \\
(38.66)^{* *}\end{array}$ \\
\hline Observations & 116 & 69 & 47 & 47 \\
\hline Adjusted R-squared & .45 & .53 & .41 & .41 \\
\hline Durbin-Watson Test & 1.91 & 2.09 & 1.96 & 1.96 \\
\hline Cook-Weisberg Test & 3.45 & 2.51 & 3.43 & 3.43 \\
\hline
\end{tabular}

Standard errors in parentheses.

* significant at $10 \% ; *$ significant at $5 \% ; * *$ significant at $1 \%$.

presented in Table 2. The impact and statistical significance of cabinet size on decree reliance over distinct values of cabinet coalescence is displayed in Figures 1 and 2.

When the full 1988-1998 period is analyzed, the factors affecting presidential choice are Congressional support, electoral cycle, cabinet coalescence, cabinet size, and the implementation of an economic plan. The Index of Congressional Support has a negative impact on decree reliance, although it is significant only at the .10 level. This provides moderate support for unilateral action theory in that the higher the level of overall legislative support for the executive, the less prone presidents were to use extraordinary means of governing. On the other 
FIGURE 1

\section{Conditional Coefficients and Statistical Significance of the Impact of Cabinet Size Upon Decree Reliance Ratio, by Cabinet Coalescence Rate, 1988-1998}

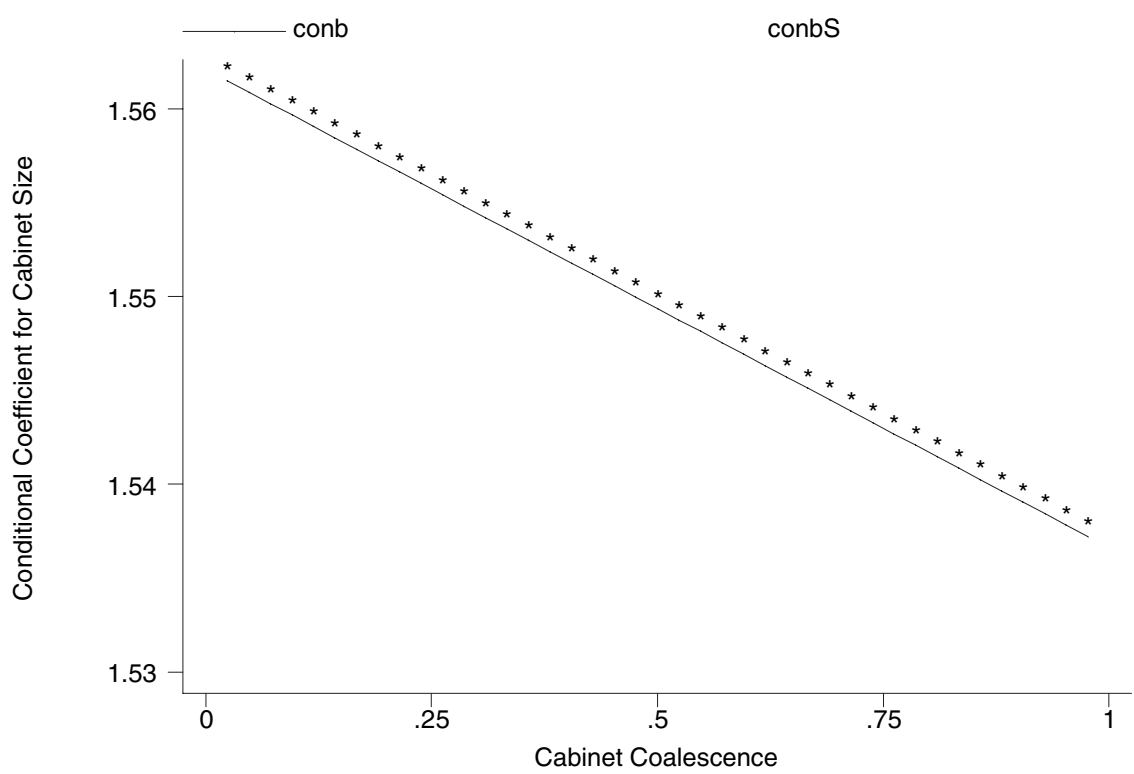

hand, during electoral months, presidents rely more heavily on decrees, which is in accordance which the expectations of delegation theory. Legislators delegate power to presidents when they face the pressures of an election. However, the impact of this variable is also barely significant. Also in accordance with delegation theory, during economic stabilization plans, which occur mostly in moments of crisis, presidents rely more often on decrees.

The impact of coalition management on the choice of policymaking instrument is not so straightforward. Table 2 indicates that cabinet size positively affects the decree reliance ratio and is statistically significant. Cabinet coalescence rate has a negative, statistically significant impact on decree reliance. ${ }^{13}$ The interaction term of cabinet size and coalescence is also negative, but the change in slope for cabinet size is not statistically significant.

\footnotetext{
${ }^{13}$ Cabinet Coalescence Rate and Cabinet Size were centered upon their grand means to facilitate the interpretation of the "main effects" of each of the variables that compose the interaction term. Given that both Cabinet Coalescence and Cabinet Size never reached a value of zero, it is more substantively interesting to interpret their impact when the other variable is held at its mean. Hence, the coefficients for each of these variables should be interpreted as the impact of that variable when the other variable is held at its mean.
} 
FIGURE 2

Conditional Coefficients and Statistical Significance of the Impact of Cabinet Size upon Decree Reliance Ratio, by Cabinet Coalescence Rate, 1988-1994

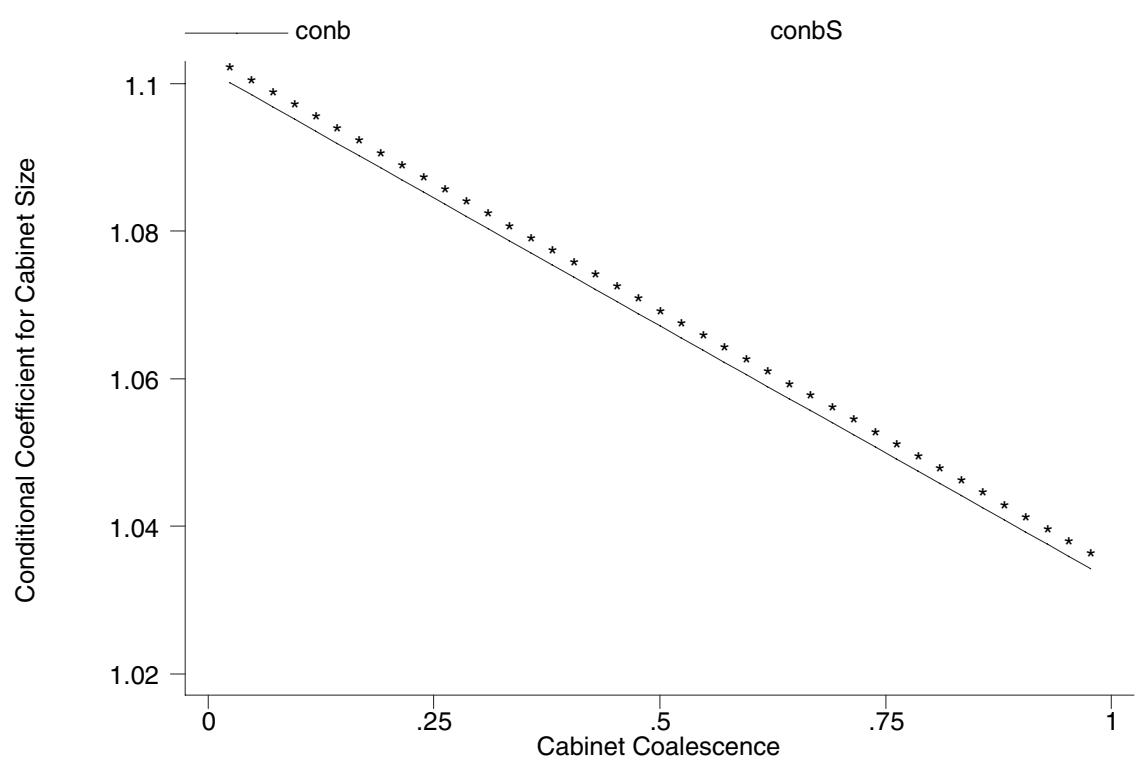

Figure 1 illustrates that the positive impact of cabinet size is mitigated by the cabinet coalescence rate. Even though the effect of cabinet size is positive on the use of decrees across all values of cabinet coalescence, the magnitude of this impact decreases as the values of coalescence rise.

In summary, a larger nominal coalition size creates incentives for presidents to rely more often on extraordinary means of governing. This supports the idea proposed by delegation theory that more politically secure presidents gain more latitude to use decree authority. Nonetheless, the coalescence rate imposes some restrictions upon presidential freedom of action. As the coalescence rate risesas the coalition becomes more evenly represented in the cabinet and presumably more influential upon presidents' choices - presidents are increasingly induced to use ordinary means of lawmaking. Therefore, our examination of the entire 1988-1998 period suggests that these distinct strategies of coalition management under minority presidentialism pose contradictory, not reinforcing, incentives to presidents.

In order to test if these relationships vary by political context, we ran similar equations for the period before and after Cardoso's inauguration. The peculiarities of the pre-Cardoso period are that the interaction term is now significant and 
the electoral cycle no longer has a statistically significant impact. The statistical significance of the interaction term indicates that the change in slope of cabinet size is significant over distinct values of cabinet coalescence. On the other hand, as Figure 2 shows, the finding that the impact of cabinet size on decree reliance diminishes as cabinet coalescence increases is identical to what we found for the entire 1988-1998 time series. Thus, these two aspects of coalition management appear to generate conflicting incentives for presidents when both are not perfectly correlated.

The model estimation for Cardoso's first term is necessarily distinct from that of his predecessors. As noted, cabinet size and cabinet coalescence rate are perfectly correlated in Cardoso's first term. Changes in the floor coalition in Congress were always mirrored by identical cabinet reshuffles. Such changes only occurred twice in Cardoso's first term, a striking departure from the practice of earlier presidents.

Given that there is perfect collinearity between cabinet size and cabinet coalescence rate, an interaction term and its two component variables cannot be entered simultaneously into the Cardoso equations. When cabinet size and cabinet coalescence rate are entered separately, both have statistically significant and positive impacts on the use of decree authority. ${ }^{14}$ When cabinet coalescence and cabinet size are both high and strongly correlated, both inclined Cardoso to rely more often on extraordinary means of governing, thus supporting the claims of delegation theory. The Cardoso experience suggests that these two strategies of coalition building have a reinforcing impact only under a specific situation: when both are strongly correlated and high. When presidents are not able to build large coalitions and/or reward them proportionally, the challenges of coalition management generate conflicting incentives as to the choice of legislative instrument.

We also find that in the Cardoso model the Index of Congressional Support has a positive impact on the use of decrees, contrary to the pattern observed for the entire 1988-1998 period. When there was preference congruence between Cardoso and Congress, he chose more often to rely on extraordinary means of governing, as would be predicted by delegation theory.

Finally, popularity is statistically significant and negative in the Cardoso period: the more popular the president was, the less he relied on decrees. By way of contrast, popularity had no effect whatsoever on Cardoso's conflict-prone predecessors, who faced lower and more inconsistent support from Congress. The earlier, more embattled presidents appear to have paid attention to the reactions of Congress rather than to those of the public. This suggests that when presidents

\footnotetext{
${ }^{14}$ We repeated an identical procedure, entering cabinet size and cabinet coalescence rate without the interaction term and then each variable separately in the equation, for the entire sample and for the Sarney-Collor-Itamar subsample. The results for the entire period and the pre-Cardoso period are identical to each other: when cabinet size and cabinet coalescence are entered simultaneously in the equation without being interacted, the former has a positive impact in the dependent variable and the latter a negative one. This impact is also maintained when they are entered separately in the equation.
} 
are embedded in more consensual environments inside Congress, public opinion does constrain the use of decree authority, but when presidents have their "backs to the wall," public opinion is irrelevant. This reading of the model is broadly consistent with unilateral action theory, although a negative and significant coefficient for popularity in the pre-Cardoso period would have provided much stronger confirmation for this interpretation.

Finally, the difference in results between Cardoso and the other presidents was tested using a Chow test. The result $[\mathrm{F}(9,98)=12.659]$ is significant at the 0.001 level, rejecting the null hypothesis that the coefficients and variances in the different samples are equal. This result provides further evidence that the Cardoso period is in fact distinct from that of his predecessors. If the two subsamples were not analyzed separately with similarly specified models, the story about the role of political variables in presidents' choices of policymaking instruments would be incomplete at best.

When the 1988-1994 and 1995-1998 periods are subjected to separate analyses, it is clear that coalition management, the mood in Congress, and presidential popularity differently affect presidents' choices in the two periods. In the first term of President Cardoso, when there is higher preference congruence between Congress and the president and when the governing coalition is large and well rewarded, Congress responds by delegating decree authority to the president, and the only limitation on its usage comes from fluctuations in the strikingly high levels of presidential popularity. In contrast, when preference congruence between presidents and Congress is lower and inconsistent, when presidents have unstable coalitions, and when presidential poll numbers are lower and less predictable - which is the case of the pre-Cardoso period - then Congress deters the use of decrees, coalition management poses contradictory incentives for lawmaking strategies, and public opinion has no palpable effect on presidential behavior.

\section{Conclusions}

Modern democracy has been characterized by a gradual shift of power from the legislature to the executive branch. Using the terminology of Cox and Morgenstern (2002), legislatures have become more reactive than proactive. Both the United States and Brazil have had spirited debates over the increasing presidential use of extraordinary mechanisms of policy making: executive orders in the United States and medidas provisórias in Brazil. Although the formal institutions are different, the basic problem of executive encroachment on legislative authority characterizes both democracies.

Unilateral action theory claims that presidents use extraordinary mechanisms in unfavorable political environments: their goal is to "bypass" uncooperative legislatures and/or to compensate for low standing in public opinion. Delegation theory, in contrast, sees executive aggrandizement as a rational strategy on the part of the legislature. Influenced by principal-agent models in the economics lit- 
erature, delegation theory claims that legislators derive benefits from having the president assume direct responsibility for policy, when such policies represent the preferences of legislators. Therefore, delegation theory predicts that presidents will resort to extraordinary mechanisms in favorable political environments, times in which policy congruence is high between different branches of government and presidents enjoy comparatively higher support from the legislature and from the public (which after all, elects both branches of government under conditions of presidentialism).

We constructed an original time-series dataset to test these hypotheses in the Brazilian case. Similar to the inconclusive findings obtained in the United States, our test of these hypotheses in Brazil met with mixed results. Our analysis generates some support for both unilateral action theory and delegation theory, but the depth of this support varies in accordance with the period analyzed. The substantive interpretation of the results can change significantly depending on whether one is analyzing specific presidents or inspecting the entire pooled analysis from 1988 through 1998.

A major turning point in our analysis was the historic Real Plan, a currency reform prepared by Finance Minister Cardoso and issued by President Itamar Franco on July 1, 1994. The presidential election of October 1994, which Cardoso won easily, was characterized by two important features: not only was it held during the honeymoon of the Real Plan (with plunging inflation and surging growth), but it was also the first time since 1950 that presidential and legislative elections were concurrent. Cardoso's allies won the governorships of important states and a majority of seats in Congress, sharply altering the political environment after his inauguration in January 1995. As Shugart and Haggard suggest: "It is no accident, we would point out, that the first president elected under concurrent elections, Fernando Henrique Cardoso, has faced a somewhat more amiable Congress" (2001, 93). Basking in the success of the Plan, Cardoso enjoyed higher popularity and more support from Congress than any of his predecessors. This permitted him to adopt an activist, multifrontal agenda: the decree reliance ratio rose even as the overall level of legislative initiatives rose across the board. The experience of the first-term Cardoso, then, lends support to the delegation literature.

Studied in isolation, Cardoso appears as a beneficiary of delegation. However, if we examine the overall pooled analysis of 10 years and four presidents (Table 2 , first column), there is some support for unilateral action theory. The comprehensive model suggests that, when we control for numerous contextual variables, decree reliance rises as congressional support declines. This is entirely in accord with the predictions of Cox and Morgenstern (2002), for whom decree usage is essentially a (negative) function of the president's support in the assembly. Thwarted by a recalcitrant Congress, presidents will use decree authority to bypass the legislature. In addition, and more importantly, different dimensions of cabinet management provide contradictory incentives to presidents in more conflict-prone environments. 
These inconsistent results suggest two preliminary observations. First, our analysis shows the limits of both the unilateral action theory and delegation approaches, insofar as there is no "one-size-fits-all" theory of presidential action. After examining the full 1988-1998 time series, we partitioned the data set in order to examine the unusual Cardoso period separately. This revealed that our empirical findings are highly sensitive to time and context. Our results demonstrated that both the unilateral action and delegation theories can fit the data, but the goodness-of-fit depends upon the broader and shifting political environment. Therefore, our mixed results can be interpreted as a plea to incorporate environmental and contextual variables more aggressively into our models and to avoid claims that certain theories fit all presidents and/or presidential democracies.

Second, to the extent that we developed support for delegation theory, our results demonstrate that delegation is contingent and conditional. It depends on a broad array of environmental variables. However, the new comparative presidentialism has not always used the term "delegation" in a consistent fashion, and, following Carey and Shugart (1998), needs to more carefully distinguish between delegation to the presidency and delegation to individual presidents. The first phenomenon is constitutional and belongs to the domain of institutional design; the second phenomenon is conditional and belongs to the domain of political process. Clearly, when framers of Brazil's 1988 constitution adopted Article 62 enshrining decree authority, they made a delegation of the first type: they delegated legislative power to the presidency of the Republic. However, the game of executive-legislative relations since 1988 has demonstrated that the limits to which presidents can actually use this authority (delegation of the second type) are highly contingent upon political and economic factors, as the experiences of Sarney, Collor, Itamar, and Cardoso all suggest.

Therefore, we need to make an analytical distinction between constitutional delegation and process-driven delegation and understand that the frequent contradictions between these concepts are precisely what is most interesting in the contemporary debate over which actor-the president or the legislature - controls the legislative agenda. Moreover, the dynamics of presidentialism and of specific presidents are not necessarily the same, so much more comparative and casestudy research is necessary in order to specify the precise determinants of decretismo. Until we can make further progress toward developing a contextually sensitive typology of decree-intensive presidentialisms, we need to exercise caution with regard to the rival claims of unilateral action and delegation theories.

\section{Appendix}

\section{Variables and Sources of Data}

MPV: Number of original medidas provisórias (presidential decrees) by month. Source: Câmara dos Deputados. 
PL: Number of projetos de lei (ordinary bills) introduced by the executive, by month. Source: Câmara dos Deputados.

PLC: Number of projetos de lei complementar (bills enabling or regulating provisions of the Constitution) introduced by the executive, by month. Source: Câmara dos Deputados.

Decree Reliance Ratio: Ratio of presidential decrees (medidas provisórias) to all forms of presidentially initiated legislation. Expressed as MPV/(MPV + PL + PLC) and calculated monthly, October 1988 through December 1998.

Presidential Popularity. The data are drawn from the three main Brazilian polling institutes: DataFolha (1988-1998), Vox Populi (1995-1998), and CNI/Ibope (1995-1998). Popularity is measured intermittently by all three institutes, so first we interpolated missing values to create full monthly series for all three. Then we checked for intersource reliability by performing correlational analysis of the interpolated time series. The interpolated DataFolha series correlates with the interpolated Vox Populi series at .95 $(\mathrm{N}=79)$ and with the interpolated Ibope series at $.96(\mathrm{~N}=78)$. Given the high reliability, we opted to create an average of the three polls for the 1995-1998 period and use the DataFolha for the earlier 1988-1994 period. In Brazil, respondents are asked to rate presidential performance as ótimo (excellent), bom (good), regular (average), ruim (bad), or péssimo (awful). Following Brazilian convention, we calculate presidential popularity by subtracting the negatives (ruim/péssimo) from the positives (ótimo/bom) and ignoring the intermediate (regular) category. Source: Web site of political journalist Fernando Rodrigues, available http://www.uol.com.br.

Legislative Support: Monthly average of the percentage of legislators following the floor recommendation (encaminhamento) of the leader of the Government in the Chamber of Deputies. In cases where the executive recommends a NO vote, the denominator is the total of votes cast in the house. In cases where the executive recommends a YES vote, the denominator is the total number of seats in the house. This variable captures legislative support for executive initiatives. In months with no floor votes, we carry forward the previous value. Source: Banco de Dados Legislativos, CEBRAP.

Cabinet Size: Nominal size of the cabinet's political "coverage." This is expressed in terms of the percentage of legislative seats held in the Chamber of Deputies by the parties represented in the presidential cabinet. Source: CABSIZE variable in Amorim Neto (2002).

Cabinet Coalescence: Similar to measures of electoral disproportionality, this is a measure of the amount of deviation between the share of cabinet ministries and the share of intracoalitional legislative seats held by parties supporting the president. The coalescence rate for a given cabinet is arrived at by adding the absolute value of the difference between the percent of portfolios and percent of legislative seats for all parties joining the cabinet (whether or not these parties have seats in the Chamber) and for all ministers (whether party members or not), and then dividing the total by 2 . Subtracting the result from 1 produces the coalescence rate. The index ranges from 0 (no correspondence between legislative 
seats and ministerial payoffs) and 1 (perfect correspondence). Source: CABINET variable in Amorim Neto (2002).

Inflation: A measure of inflation, using the consumer price index maintained by IBGE, the Brazilian census bureau. Source: IPEA Web site (http://www.ipea.gov.br).

Economic Plan: Coded as 1 in months in which there was a major economic "stabilization package" or "economic plan" introduced by the executive, and 0 in all other months. The relevant months are January 1989 (Plano Verão), March 1990-b (Plano Collor), December 1990 (Plano Collor II), December 1993 (URV), and June 1994 (Plano Real).

Honeymoon: A dummy where 1 represents the first three months of each presidential administration (except Sarney, who had already been in office more than three years when our analysis begins in 1988) and 0 the rest.

Reelectability: Dummy where 1 represents the change to allow consecutive reelection of presidents in Brazil. June 1997 onward equals 1, the rest 0.

Election: Attempts to gauge the disruption to normal parliamentary activity caused by an impending presidential or legislative election. Scored as 1 for September, October, and November in the years of 1989 and 1994; also scored as 1 for September and October 1998; all other months coded 0.

\section{Acknowledgments}

Earlier versions of this article were presented at the third meeting of the Brazilian Political Science Association (ABCP), Niterói, Rio de Janeiro, 2002, and at the 2002 annual meeting of the American Political Science Association, Boston. The authors are grateful to Octávio Amorim Neto for supplying data on cabinet formation and to Argelina Figueiredo and Fernando Limongi for supplying roll-call data from the Banco de Dados Legislativos, version 2002, at CEBRAP (São Paulo). We would also like to thank David Barker, Chris Bonneau, Taeko Hiroi, James Kim, Scott Morgenstern, Aníbal Pérez-Liñán, David Samuels, Fabiano Santos, and three anonymous reviewers for helpful comments. The usual disclaimer applies.

Manuscript submitted March 3, 2003

Final manuscript received July 19, 2004

\section{References}

Abranches, Sergio Hudson de. 1988. "Presidencialismo de coalizão: o dilema institucional brasileiro." Dados 31(1): 5-38.

Achen, Christopher H. 2000. "Why Lagged Dependent Variables Can Suppress the Explanatory Power of Other Independent Variables." Presented at the Annual Meeting of the Political Methodology Section of the American Political Science Association, UCLA.

Ames, Barry. 2001. The Deadlock of Democracy in Brazil. Ann Arbor: University of Michigan Press. 
Amorim Neto, Octávio. 2002. "Presidential Cabinets, Electoral Cycles, and Coalition Discipline in Brazil." In Legislative Politics in Latin America, eds. Scott Morgenstern and Benito Nacif. New York: Cambridge University Press, pp. 48-78.

Amorim Neto, Octávio, Gary D. Cox, and Mathew D. McCubbins. 2003. "Agenda Power in Brazil's Câmara dos Deputados, 1989 to 1998." World Politics 55(4): 550-78.

Amorim Neto, Octávio, and Paulo Tafner. 2002. "Governos de coalizão e mecanismos de alarme de incêndio no controle legislativo das medidas provisórias." Dados 45(1): 5-58.

Carey, John, and Matthew Soberg Shugart, eds. 1998. Executive Decree Authority: Calling Out the Tanks or Filling Out the Forms? New York: Cambridge University Press.

Cooper, Philip J. 1986. "By Order of the President: Administration by Executive Order and Proclamation." Administration and Society 18(2): 233-62.

Cox, Gary W., and Scott Morgenstern. 2002. "Epilogue: Latin America's Reactive Assemblies and Proactive Presidents.” In Legislative Politics in Latin America, eds. Scott Morgenstern and Benito Nacif. New York: Cambridge University Press, pp. 446-68.

Epstein, David, and Sharyn O'Halloran. 1999. Delegating Powers: A Transaction Cost Politics Approach to Policv Making under Separate Powers. Cambridge: Cambridge University Press.

Figueiredo, Argelina, and Fernando Limongi. 1999. Executivo e Legislativo na Nova Ordem Constitucional. Rio de Janeiro: Editora Fundação Getúlio Vargas.

Figueiredo, Argelina, and Fernando Limongi. 2003. "Congress and Decision-Making in Democratic Brazil.” In Brazil Since 1985: Economy, Polity, and Society, eds. Maria D'Alva Gil Kinzo and James Dunkerley. London: Institute of Latin American Studies, University of London, pp. 62-83.

Gleiber, Dennis W., and Steven A. Shull. 1992. "Presidential Influence in the Policymaking Process." Western Political Ouarterlv 45(2): 441-67.

Huber, John D. 1996. Rationalizing Parliament. Cambridge: Cambridge University Press.

Huber, John D. 1998. "Executive Decree Authority in France." In Executive Decree Authority: Calling Out the Tanks or Filling Out the Forms?, eds. John Carey and Matthew Soberg Shugart. New York: Cambridge University Press, pp. 233-53.

Kiewiet, D. Roderick, and Matthew McCubbins. 1991. The Logic of Delegation: Congressional Parties and the Appropriations Process. Chicago: The University of Chicago Press.

Krause, George A., and David B. Cohen. 1997. "Presidential Use of Executive Order, 1953-1994." American Politics Ouarterly 25(4): 458-71.

Lowi, Theodore. 1985. The Personal President. Ithaca: Cornell University Press.

Mainwaring, Scott. 1993. "Presidentialism, Multipartism, and Democracy: The Difficult Combination." Comparative Political Studies 26(2): 198-228.

Mayer, Kenneth R. 1999. "Executive Orders and Presidential Power." Journal of Politics 61(2): $445-66$.

McCubbins, M. D., R. Noll, and B. R. Weingast. 1987. “Administrative Procedures as Instruments of Political Control." Journal of Law, Economics and Organization 3(2): 234-77.

McCubbins, M. D., R. Noll, and B. R. Weingast. 1989. "Structure and Process, Politics and Policy: Administrative Arrangements and Political Control of Agencies." Virginia Law Review 75(2): $431-82$.

Moe, Terry M., and William G. Howell. 1999. "Unilateral Action and Presidential Power: A Theory." Presidential Studies Ouarterly 29(4): 850-72.

Neustadt, Richard. 1960. Presidential Power: The Politics of Leadership. New York: John Wiley.

Pereira, Carlos, and Bernardo Mueller. 2002. "Credibility and Design of Regulatory Agencies in Brazil." Brazilian Journal of Political Economy 22(3): 65-88.

Pereira, Carlos, and Lucio Rennó. 2003. "Successful Re-Election Strategies in Brazil: The Electoral Impact of Distinct Institutional Incentives." Electoral Studies 22(3): 425-48.

Pessanha, Charles. 2002. "O Poder Executivo e o processo legislativo nas constituições brasileiras: teoria e prática.” Unpublished manuscript, IUPERJ, Rio de Janeiro.

Power, Timothy J. 1998. "The Pen is Mightier than the Congress: Presidential Decree Authority in Brazil." In Executive Decree Authority: Calling Out the Tanks or Filling Out the Forms?, eds. John M. Carey and Matthew Soberg Shugart. New York: Cambridge University Press, pp. 197-232. 
Reich, Gary. 2002. "Executive Decree Authority in Brazil: How Reactive Legislators Influence Policy." Legislative Studies Ouarterlv 27(1): 5-31.

Samuels, David J. 2002. "Progressive Ambition, Federalism, and Pork-Barreling in Brazil." In Legislative Politics in Latin America, eds. Scott Morgenstern and Benito Nacif. New York: Cambridge University Press, pp. 315-40.

Shugart, Matthew Soberg, and John M. Carey. 1992. Presidents and Assemblies: Constitutional Design and Electoral Dynamics. New York: Cambridge University Press.

Shugart, Matthew Soberg, and Stephan Haggard. 2001. "Institutions and Public Policy in Presidential Systems." In Presidents, Parliaments, and Policy, eds. Stephan Haggard and Matthew D. McCubbins. New York: Cambridge University Press, pp. 64-102.

Stokes, Susan C., ed. 2001. Public Support for Economic Reforms in New Democracies. New York: Cambridge University Press.

Weyland, Kurt. 2002. The Politics of Market Reform in Fragile Democracies: Argentina, Brazil, Peru, and Venezuela. Princeton: Princeton University Press.

Carlos Pereira (pereirace@uol.com.br) is visiting professor and researcher of economics, University of São Paulo, 05508-900, São Paulo, Brazil, and associate researcher at the Fundação Oswaldo Cruz, São Paulo, Brazil. Timothy J. Power (powertj@fiu.edu) is associate professor of political science, and president of the Brazilian Studies Association, Florida International University, Miami, FL 33199. Lucio Rennó (lucio_renno@yahoo.com) is Rockefeller Fellow at the Latin American and Carribean Studies Center at the State University of New York at Stony Brook and assistant professor of political science, University of Arizona, Tucson, AZ 85721-0158. 